\title{
Plasticity in habitat use of two native Ponto-Caspian gobies, Proterorhinus semilunaris and Neogobius fluviatilis: implications for invasive populations
}

\author{
Nildeniz Top ${ }^{1, *}$, Uğur Karakuş ${ }^{1}$, Erdi Gökhan Tepeköy ${ }^{1}$, John Robert Britton ${ }^{2}$ and Ali Serhan Tarkan ${ }^{1,3}$ \\ ${ }^{1}$ Research and Application Unit, Faculty of Fisheries, Muğla Sitkı Koçman University, 48000 Menteşe, Muğla, Turkey \\ 2 Department of Life and Environmental Sciences, Faculty of Science and Technology, Bournemouth University, Poole, Dorset, BH12 5BB, UK \\ ${ }^{3}$ Department of Ecology and Vertebrate Zoology, Faculty of Biology and Environmental Protection, University of Łódź, Łódź, Poland
}

Received: 3 April 2019 / Accepted: 7 September 2019

\begin{abstract}
The Ponto-Caspian region is an important source area for some invasive gobiid fishes. These fishes have colonised several freshwater ecosystems in Europe, as well as in North America. As knowledge on their habitat utilisation in their native range remains limited, the seasonal habitat uses of Western tubenose goby, Proterorhinus semilunaris and monkey goby Neogobius fluviatilis were studied in four natural lakes in the Marmara Region (NW Turkey). Habitat use of both species was highly variable between the lakes and seasons, with $P$. semilunaris showing higher plasticity. In general, the main habitats used by $P$. semilunaris were shallow waters in littoral areas that had vegetation cover, whereas $N$. fluviatilis consistently used sandy substratum in deeper waters that lacked vegetation. These results suggested there was high plasticity in the habitat utilisation of these two gobiids, especially in P. semilunaris, which potentially facilitates their ability to establish and invade novel environments. The habitats that are especially vulnerable to $P$. semilunaris invasion are medium size substrates which provide individuals with sufficient interstitial space for refuge. Waters providing differing habitats, such as sandy substrata, might inhibit their colonisation, but are potentially more vulnerable to $N$. fluviatilis invasion.
\end{abstract}

Keywords: Gobiidae / microhabitat / natural lakes / native range / habitat plasticity

Résumé - Plasticité dans l'utilisation de l'habitat de deux gobies natifs de la région PontoCaspienne, Proterorhinus semilunaris et Neogobius fluviatilis : implications pour les populations envahissantes. La région de Ponto-Caspienne est une source importante de certains poissons gobiidés envahissants. Ces poissons ont colonisé plusieurs écosystèmes d'eau douce en Europe, ainsi qu'en Amérique du Nord. Comme les connaissances sur l'utilisation de leur habitat dans leur aire de répartition indigène restent limitées, les utilisations saisonnières de l'habitat du gobie demi-lune, Proterorhinus semilunaris et du gobie fluviatile Neogobius fluviatilis ont été étudiées dans quatre lacs naturels de la région de Marmara (Nord-Ouest de la Turquie). L'utilisation de l'habitat des deux espèces était très variable entre les lacs et les saisons, $P$. semilunaris présentant une plus grande plasticité. En général, les principaux habitats utilisés par $P$. semilunaris étaient des eaux peu profondes dans les zones littorales couvertes de végétation, alors que $N$. fluviatilis utilisait systématiquement un substrat sablonneux dans les eaux profondes dépourvues de végétation. Ces résultats suggèrent une grande plasticité dans l'utilisation de l'habitat de ces deux gobiidés, en particulier chez $P$. semilunaris, ce qui facilite potentiellement leur capacité à s'établir et à envahir de nouveaux environnements. Les habitats particulièrement vulnérables à l'invasion de $P$. semilunaris sont des substrats de taille moyenne qui fournissent aux individus un espace interstitiel suffisant pour se réfugier. Les eaux offrant des habitats différents, comme les substrats sableux, peuvent inhiber leur colonisation, mais sont potentiellement plus vulnérables à l'invasion de $N$. fluviatilis.

Mots-clés : Gobiidae / microhabitat / lacs naturels / aire de répartition indigène / plasticité de l'habitat

\footnotetext{
*Corresponding author: tnildeniz@gmail.com
} 


\section{Introduction}

Non-native species continue to be introduced outside of their natural range, resulting in their range expansion and the development of invasive populations that impact native biodiversity (Lockwood et al., 2007; Seebens et al., 2017). Integral to determining the ability of an introduced species to establish and develop invasive populations is their adaptation to the available foraging and spawning habitat in the introduced environment (Van Kessel et al., 2011; Top et al., 2016). Generalist species that have high plasticity in their habitat selectivity are often more successful invaders, as there are lower costs involved in their adaptation to the new environment (Gozlan et al., 2010; Davidson et al., 2011). Consequently, developing understandings of the habitat use and plasticity of utilisation of invasive species in their native range can help inform invasion risk assessments (Copp et al., 2009, 2016).

The Ponto-Caspian (P-C) region (Black Sea, Sea of Azov and Caspian Sea) remains an important donor region of many invasive species, including invasive gobiid fishes (Roche $\mathrm{et} \mathrm{al.,}$ 2013). Invasions of P-C gobies are now apparent across much of Europe (Wiesner, 2005, Naseka, 2005, Rizevsky et al., 2007, Antsulevich, 2007, Janáč et al., 2012, Konečná and Jurajda, 2012) and in North America (Dillon and Stepien, 2001; Kornis and Vander, 2010; Kocovsky et al., 2011). Invasive gobiids include the western tubenose goby Proterorhinus semilunaris and the monkey goby Neogobius fluviatilis. Their native range is the Black Sea region of Turkey, where they represent an important component of native fish communities and have value for food consumption (Özuluğ et al., 2005; Çınar et al., 2013; Tarkan et al., 2018). The transport of $N$. fluviatilis into Europe was via ship ballast waters at major ports, followed by natural dispersal into inland freshwaters thereafter, which resulted in their invasion (Copp et al., 2005; Grabowska et al., 2009; Jakovlič et al., 2015). In North America, N. fluviatilis has been listed as a potentially high-impact non-native species in the Great Lakes (Pagnucco et al., 2015). The introduction of $P$. semilunaris into Europe occurred in the early 1990 s, presumably by anglers using them as live bait (Lusk and Halačka, 1995), and to North America in 1990 (the Laurentian Great Lakes, St. Clair River) via ballast water release (Jude et al., 1992). Although the invasion of $P$. semilunaris has been spatially constrained due to the dispersal restrictions of being within lake systems (e.g. Lake St. Clair and Erie; Vanderploeg et al., 2002), studies of invading populations in Europe (e.g. the Danube Basin) have demonstrated negative impacts on macroinvertebrate communities through predation (Všetičková et al., 2014).

For P. semilunaris and $N$. fluviatilis, ecological knowledge on their populations in their native range is limited, but has recently increased in relation to the expression of their life history traits and their trophic relationships with other species (Tarkan et al., 2018; Karakuş et al., 2018; Top et al., 2018). There remain, however, considerable knowledge gaps in the habitat use of both native $P$. semilunaris and $N$. fluviatilis, as well as other common gobiids, such as round goby Neogobius melanostomus (Kornis et al., 2012). Indeed, there is only a single study on microhabitat use of $P$. semilunaris completed in their native Turkish range (Gürsoy Gaygusuz et al., 2010). For
N. fluviatilis, literature is limited to indirect reports arising during ichthyofaunal studies (Berg, 1949; Svetovidov, 1964, Sindilariu et al., 2006). There is also very limited information on seasonal differences in habitat use for both species, with only a single study from the invasive range of $N$. fluviatilis (Erös et al., 2005). Consequently, these knowledge gaps on the utilisation of habitats of these P-C gobies in their native range presents a considerable challenge for horizon scanning exercises and invasion risk assessment processes for these fishes in their non-native range. This is despite these exercises and processes being essential components of the invasion risk management toolkit (Britton et al., 2011; Roy et al., 2014). The aim of this study was, therefore, to overcome this knowledge gap through quantifying the seasonal habitat use of $P$. semilunaris and $N$. fluviatilis across an environmental gradient in their native range.

\section{Materials and methods}

\subsection{Study sites}

Four natural lakes in the Marmara Region (north-west Anatolia, Turkey) were used in the study; two were relatively shallow (Manyas and Uluabat) and two were relatively deep (İznik and Sapanca) (Tab. 1, Fig. 1). Both P. semilunaris and $N$. fluviatilis are considered as native to the lakes (e.g. Numann, 1958). These lakes provided a range of physical environments that enabled inter-lake differences to be assessed in relation to the species' seasonal habitat use. However, in the two deeper lakes (İznik and Sapanca), gobies were not captured from the deeper areas, only in littoral areas $(<1.5 \mathrm{~m}$ deep). The fish assemblages of all lakes were dominated by fishes of the Cyprinidae family; other native gobiids were present, including round goby Neogobius melanostomus and Caucasian dwarf goby Knipowitchia caucasica. Other fishes present included northern pike Esox lucius, European catfish Silurus glanis, gibel carp Carassius gibelio, Eastern mosquitofish Gambusia holbrooki, pumpkinseed Lepomis gibbosus and topmouth gudgeon Pseudorasbora parva, most of which are alien species to the lakes (Geldiay and Balık, 2009).

Lake İznik is a deep (to $80 \mathrm{~m}$ ) tectonic lake, but with shallower deltas around the lake shore, fringed with reeds where tributary streams enter. The lake's trophic status has shifted from oligotrophic to mesotrophic in recent decades due to high agricultural activity around the lake, coupled with waste-waters from nearby residential areas (Akçaalan et al., 2009). The most abundant fish species present is $P$. semilunaris, enabling their capture from littoral habitats. However, samples collected in autumn were poor due to adverse weather conditions at the time of sampling. Lake Sapanca is also a deep (to $55 \mathrm{~m}$ ) tectonic lake fed by numerous small streams. The lake suffers from substantial water level fluctuations and frequent algal blooms due to abstraction for potable water and high agricultural activity in the catchment. These water level fluctuations negatively impacted the littoral area during the sampling period, resulting in the absence of gobies in samples from these areas. Consequently, samples of P. semilunaris were instead mainly collected from the mouth of five steep mountain streams feeding into the lake.

Both Lake Manyas and Uluabat have a RAMSAR designation, and are also impacted by abstraction and nutrient 
N. Top et al.: Knowl. Manag. Aquat. Ecosyst. 2019, 420, 40

Table 1. Latitude (Lat), longitude (Lon), surface area (SA, $\mathrm{km}^{2}$ ), altitude (Alt, m), minimum (Min), maximum (Max) and mean temperature $\left({ }^{\circ} \mathrm{C}\right)$, mean and maximum depth $(\mathrm{m})$ of four lakes in the Marmara Region (Karakuş et al., 2018; Top et al., 2018).

\begin{tabular}{|c|c|c|c|c|c|c|c|c|c|}
\hline \multirow[b]{2}{*}{ Lake } & \multirow[b]{2}{*}{ Lat } & \multirow[b]{2}{*}{ Lon } & \multirow[b]{2}{*}{ SA } & \multirow[b]{2}{*}{ Alt } & \multicolumn{3}{|c|}{ Temperature } & \multicolumn{2}{|c|}{ Depth } \\
\hline & & & & & Min & Max & Mean & Mean & Max \\
\hline İznik & $40^{\circ} 26^{\prime}$ & $29^{\circ} 32^{\prime}$ & 313 & 85 & 7.2 & 28.4 & 16.4 & 40.0 & 80.0 \\
\hline Sapanca & $40^{\circ} 42^{\prime}$ & $30^{\circ} 15^{\prime}$ & 47 & 30 & 8.4 & 27.5 & 15.8 & 26.0 & 55.0 \\
\hline Uluabat & $40^{\circ} 10^{\prime}$ & $28^{\circ} 35^{\prime}$ & 136 & 9 & 4.1 & 28.9 & 18.1 & 2.5 & 4.5 \\
\hline Manyas & $40^{\circ} 12^{\prime}$ & $27^{\circ} 56^{\prime}$ & 178 & 18 & 7.1 & 27.1 & 18.6 & 1.5 & 3.6 \\
\hline
\end{tabular}

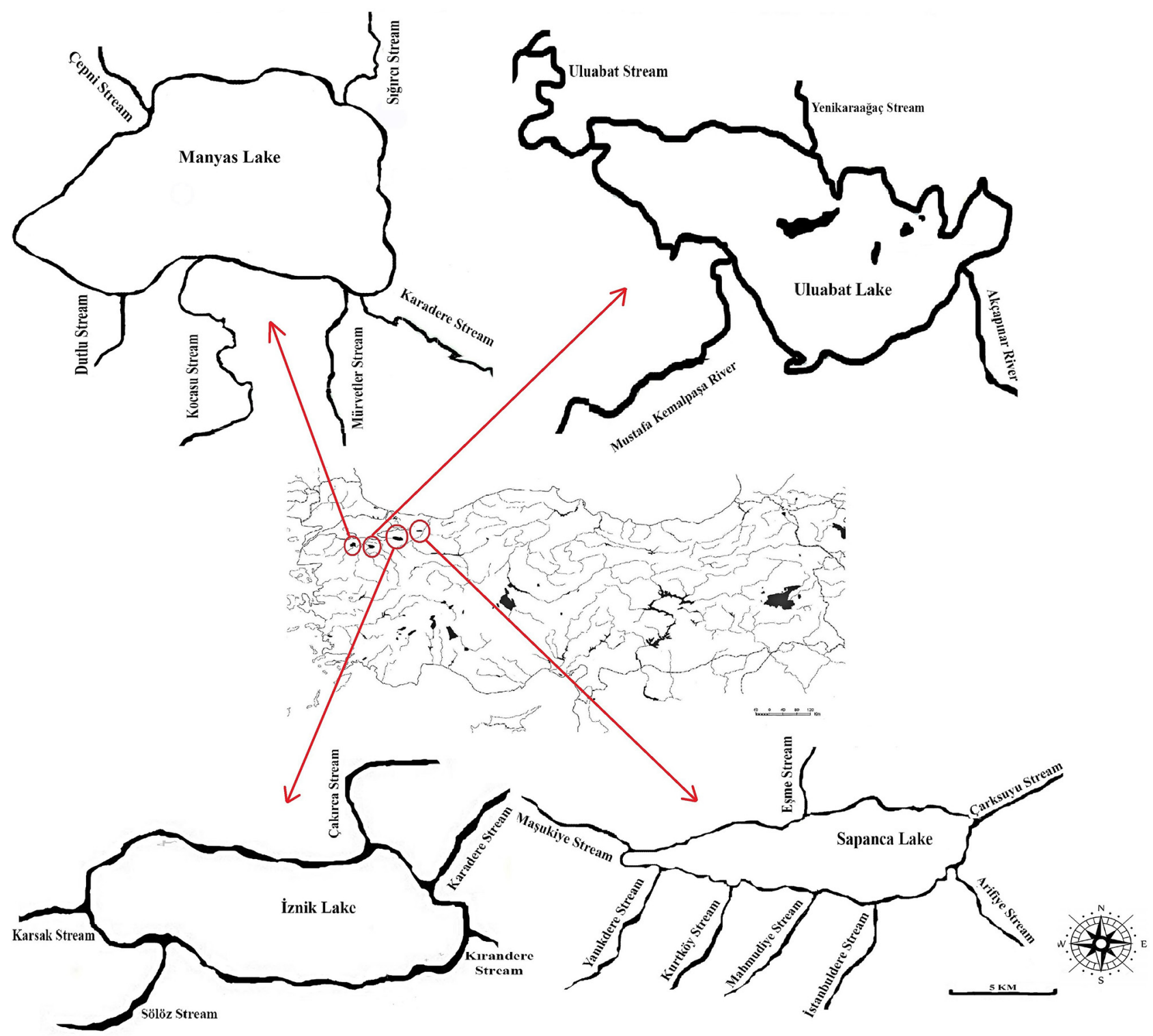

Fig. 1. Study sites (mouths of the streams) in the Marmara region (north-west Turkey) for Western tubenose goby Proterorhinus semilunaris and monkey goby Neogobius fluviatilis.

enrichment, resulting in water level fluctuations and algal blooms (Magnin and Yarar, 1997; Albay and Akçaalan, 2003; Arslan et al., 2010). In Lake Manyas, sampling sites for $N$. fluviatilis were located in mouths of the small creeks generally characterised by muddy to sandy substrata and some large rocks. In Lake Uluabat. P. semilunaris was abundant in the littoral areas, with $N$. fluviatilis collected both from littoral areas and deeper parts of the lake. 
N. Top et al.: Knowl. Manag. Aquat. Ecosyst. 2019, 420, 40

Table 2. Seasonal variations between total number of specimens caught and percentage of goby presence on sampled points and $p$-values of $\chi^{2}$ test for differences between seasons $(p<0.001$ means there are significant differences).

\begin{tabular}{|c|c|c|c|c|c|}
\hline & & Sampled points & Total number of specimens & $\%$ with goby presence & $p$-value between seasons \\
\hline \multicolumn{6}{|c|}{ P. semilunaris } \\
\hline \multirow{4}{*}{ İznik } & Autumn & 50 & - & - & \multirow{4}{*}{$<0.001$} \\
\hline & Winter & 50 & 32 & 57 & \\
\hline & Spring & 50 & 30 & 54 & \\
\hline & Summer & 50 & 34 & 63 & \\
\hline \multirow{4}{*}{ Sapanca } & Autumn & 50 & 36 & 58 & \multirow{4}{*}{$<0.001$} \\
\hline & Winter & 50 & - & - & \\
\hline & Spring & 50 & 30 & 53 & \\
\hline & Summer & 50 & 34 & 63 & \\
\hline \multirow{4}{*}{ Uluabat } & Autumn & 50 & 51 & 92 & \multirow{4}{*}{$<0.001$} \\
\hline & Winter & 50 & 18 & 20 & \\
\hline & Spring & 50 & 29 & 47 & \\
\hline & Summer & 50 & 28 & 46 & \\
\hline \multicolumn{6}{|c|}{ N. fluviatilis } \\
\hline \multirow{4}{*}{ Sapanca } & Autumn & 50 & - & - & \multirow{4}{*}{$\mathrm{n} / \mathrm{a}$} \\
\hline & Winter & 50 & - & - & \\
\hline & Spring & 50 & 18 & 32 & \\
\hline & Summer & 50 & - & - & \\
\hline \multirow{4}{*}{ Manyas } & Autumn & 50 & 21 & 41 & \multirow{4}{*}{0.45} \\
\hline & Winter & 50 & 31 & 60 & \\
\hline & Spring & 50 & 34 & 66 & \\
\hline & Summer & 50 & 34 & 65 & \\
\hline \multirow{4}{*}{ Uluabat } & Autumn & 50 & 21 & 41 & \multirow{4}{*}{0.003} \\
\hline & Winter & 50 & 15 & 26 & \\
\hline & Spring & 50 & 33 & 65 & \\
\hline & Summer & 50 & 34 & 65 & \\
\hline
\end{tabular}

\subsection{Fish sampling and habitat data collection}

Sampling of the gobies was completed seasonally (summer, autumn, winter, spring) between August 2014 and May 2015 using Point Abundance Sampling (PAS: Nelva et al., 1979) by electric fishing (SAMUS-725MP; the radius of the electricity around the anode was approximately $2 \mathrm{~m}$ ). This method provides reproducible and quantifiable samples of fish, and is efficient across the entire length range of the focal species (Copp, 1989). On each sampling occasion per lake, 50 selected points were sampled within a predefined area by wading. The sampling areas were approximately $3 \mathrm{~m}$ from the bank, especially around river mouths in Lake Sapanca. Within these areas, all accessible habitats under $1 \mathrm{~m}$ depth were sampled, except those that were inaccessible due to dense plant growth. The area in which the point samples were taken were kept consistent between seasonal samples where possible, although water level fluctuations in Lakes Sapanca and Uluabat prevented this, with more open water areas sampled during seasons of relatively low water levels.

Sampling was carried out in each point with the power of the electric fishing equipment turned on for $10 \mathrm{~s}$ and all fish in the vicinity of the anode ring being captured with a hand net. The fish were then held in water filled bucket, before being identified to species, counted and measured. Measurements of microhabitat variables were as per Beyer et al. (2007): (i) depth (to nearest $\mathrm{cm}$ ), (ii) substratum composition (visually estimated as: mud, $<50 \mu \mathrm{m}$; silty sand, $>50 \mu \mathrm{m}$ to $0.06 \mathrm{~cm}$; sand, $>0.06-0.2 \mathrm{~cm} ;$ gravel, $>0.2-2.0 \mathrm{~cm} ; \mathrm{mud}+$ stone, $>2.0-20.0 \mathrm{~cm}$; rock, $>20 \mathrm{~cm}$, (iii) distance from bank $(\mathrm{cm})$, (iv) distance from vegetation ( $\mathrm{cm})$, (v) submersed aquatic vegetation, (vi) submersed woody structure (roots or other ligneous material), (vii) plant cover (all in \% of point area), (viii) water velocity, (ix) turbidity (estimated visually as: low, medium and high), and (x) light intensity (at the water surface and categorised as: shady, sunny-shady, and sunny).

\subsection{Data analysis}

Chi-square test was used to test seasonal variations between percentage of goby presence on sampled points. The seasons with no presence data were not included in this analysis (Tab. 2). Fish-habitat relationships were analysed by Constrained Quadratic Ordination (CQO) (Yee, 2004). This method overcomes the unrealistic assumptions of equal tolerances, equal maxima and uniformly distributed optima and site scores over the range of the environmental gradient, unlike Canonical Correspondence Analysis (CCA) (Yee, 2004), and has been applied successfully to fish-habitat relationships studies (Vilizzi et al., 2012; Top et al., 2016). CQO estimates an optimal linear combination of the microhabitat variables and regresses the species' data upon the latent variable axis using a quadratic curve 
fitted across the species' scores. In the analyses, each response curve in the ordination diagram represents the distributional range of the species across the microhabitat gradient (i.e. the latent variable). Hence, the relative position of the curve along the gradient indicates the preference of the species for certain values of the microhabitat variables summarised into the microhabitat gradient, and as determined by the species' probability of occurrence (as the fish data are entered as presence/absence), which indicates the optimum value (Yee, 2004). CQO was fitted under a binomial model of rank 1, with three non-linear degrees of freedom and unequal tolerances and after choice of the 'best' 100 models (Yee, 2006). Models were run in R x64 v3.0.3 (R Development Core Team, 2015) using library VGAM v0.9-7. Negative scores correspond to a higher value of the descriptor (and optimum) on the left-hand axis of the CQO plot, positive scores to a higher value of the descriptor on the right-hand axis.

Individual CCA models were run for each seasonal sampling occasion per lake and gobiid species. The data entered in each model were the presence/absence (as 1/0) of the gobiid species, and then the 10 descriptors that identify the microhabitat latent variable (depth, substratum composition, distance from bank, distance from vegetation, submersed aquatic vegetation, submersed woody structure, plant cover, velocity, turbidity and light intensity).

\section{Results}

\subsection{Fish samples}

In total, 563 gobiids were sampled (322 P. semilunaris and $241 \mathrm{~N}$. fluviatilis) across the entire study. A total of 800 point samples was used for the habitat use analysis, out of which gobies were present at 506 points $(63.3 \%)$. In each lake, there were some seasonal differences in the proportion of point samples where the gobies were captured, with the highest proportions generally in spring and summer, and the lowest in winter and autumn (Tab. 2). Between the species and across the four lakes, $P$. semilunaris was recorded in a significantly higher proportion of points than N. fluviatilis $\left(\chi^{2}=0.0001, P<\right.$ $0.001)$. In general, points where both gobies were present among all sites tended to be relatively shallow with a coarser substratum, with relatively low turbidity and more vegetated than points where they were absent (Tab. 3).

In Lake Manyas, P. semilunaris were sampled in very low numbers so they were excluded from further analyses, whereas $N$. fluviatilis was not present in Lake İznik. There were not enough $P$. semilunaris specimens to plot CQO diagram in autumn for Lake İznik. Similarly, N. fluviatilis individuals could be captured only in spring and no species were captured in the winter survey from Lake Sapanca (Tab. 2, Fig. 2).

\subsection{Habitat use of $\boldsymbol{P}$. semilunaris}

Abundance and percentage of $P$. semilunaris presence were significantly higher in Lake Uluabat than in Lakes Sapanca and İznik $(P<0.001$; Tab. 2). In Lake İznik, $P$. semilunaris were present in points with coarser stones in more turbid waters with vegetation, especially close to the riparian zone, and were less likely to be captured from relatively deeper areas in winter and spring. However, in summer, finer substrate was used and the species tended to be in deeper water with plant cover that was located further from the lake shore. Although there was consistency in avoiding areas of water velocity and woody structures in all seasons, there was generally high variability in habitat use (Fig. 2; Tab. 3).

In Lake Sapanca, P. semilunaris always avoided areas of deeper water over fine substrates and most specimens occurred around riparian trees in areas of no flow in spring and autumn. In summer, they tended to be closer to vegetated areas and stream mouths (Tab. 3, Fig. 2). In general, there was no specific habitat use of $P$. semilunaris in Sapanca, with fish sampled from all combinations of substrates and water levels, especially in spring. In Lake Uluabat, P. semilunaris also had few seasonal differences in their habitat use, except for spring when it was detected in most of habitat types. In summer, when there was a decrease in water level, they revealed a shift in habitat use to either being present further from the shore or to points with increased vegetation cover (Tab. 3, Fig. 2).

\subsection{Habitat use of $\mathbf{N}$. fluviatilis}

The presence and abundance of $N$. fluviatilis was significantly lower in Lake Sapanca than in Lakes Uluabat and Manyas (Tab. 2). In Sapanca, N. fluviatilis was only present in spring, when they were captured from $32 \%$ of the points sampled (Tab. 2) and they used deeper habitats without vegetation, flow and woody structure (Tab. 3, Fig. 2). In Lake Manyas, habitat use of $N$. fluviatilis varied significantly between the seasons, with no specific habitat affinity in autumn (Tabs. 2 and 3). However, in summer and winter, they were generally found in deeper water with minimal vegetation and riparian tree cover (Tab. 3, Fig. 2). Conversely, in spring, their presence increased with distance from the bank and over finer substratum (Fig. 2). In Lake Uluabat, there were no significant differences in habitat use of $N$. fluviatilis between seasons $(P=0.45$; Tab. 2), with fish tending to avoid deeper waters and vegetated areas with riparian trees in all seasons (Tab. 2).

\section{Discussion}

The two gobiids have previously been reported to have variable microhabitat use in their native (e.g. Gürsoy Gaygusuz et al., 2010) and non-native ranges (e.g. Erös et al., 2005; Janáč et al., 2012). This suggests some adaptive capacity of both species regarding habitat utilization (e.g. Karakuş et al., 2018; Top et al., 2018). The results here are congruent with this, with both native gobiids revealing high variability in their habitat use, with this apparent between seasons and lakes. This plasticity in habitat use enhances their ability to colonise and invade new environments, and is thus important for informing their invasion risk management (Copp et al., 2009; Britton et al., 2011).

Comparisons of $P$. semilunaris habitat utilisation data here with other studies revealed some consistencies and emphasised the high plasticity in their habitat utilisation. For example, the habitat uses of age $0+P$. semilunaris in two connected rivers in the non-native range of the Danube River Basin revealed a tendency for inhabiting areas comprising of relatively large stones $(10-30 \mathrm{~cm})$ and avoidance of areas of fine substrates, such as silt, sand and gravel (Grabowska et al., 2008; Janáč 
Table 3. Constrained Quadratic Ordination (CQO) results for occurrence of Proterorhinus semilunaris and Neogobius fluviatilis from four natural lakes over four seasons. For each component, scores of the descriptors on the latent microhabitat variable are given. For each species, the optimum and tolerance on the range of the latent variable are indicated. Negative scores correspond to a higher value of the descriptor (and optimum) on the left-hand axis of the CQO plot, positive scores to a higher value of the descriptor on the right-hand axis ( $c f$. Fig. 2). (DFB: distance from bank, DFV: distance from vegetation, SAV: submersed aquatic vegetation, SWS: submersed woody structure, PC: plant cover).

\begin{tabular}{|c|c|c|c|c|c|c|c|c|c|c|c|c|c|}
\hline Lake & CQO & Optimum & Tolerance & Depth & Substratum & DFB & DFV & SAV & SWS & $\mathrm{PC}$ & Velocity & Turbidity & Light \\
\hline \multirow{6}{*}{ İznik } & Winter & & & 3.146 & -1.727 & -1.701 & 0.237 & -2.218 & 3.813 & 0.595 & 1.638 & -0.174 & 2.031 \\
\hline & P. semilunaris & -0.943 & 1.000 & & & & & & & & & & \\
\hline & Spring & & & 1.925 & 0.623 & -2.553 & 0.872 & 0.905 & 1.345 & -2.490 & -1.137 & 1.420 & -2.632 \\
\hline & P. semilunaris & -0.253 & 1.000 & & & & & & & & & & \\
\hline & Summer & & & 3.449 & 0.336 & -2.400 & 0.205 & -0.387 & -0.161 & 1.950 & -1.090 & 0.466 & 3.240 \\
\hline & P. semilunaris & 2.582 & 1.000 & & & & & & & & & & \\
\hline \multirow{7}{*}{ Sapanca } & Autumn & & & -0.111 & 0.242 & -0.370 & 0.491 & 0.174 & -0.226 & 0.581 & 0.055 & -1.042 & 1.386 \\
\hline & P. semilunaris & 1.572 & 1.000 & & & & & & & & & & \\
\hline & Spring & & & 0.234 & -0.122 & -0.011 & -0.089 & -0.053 & 0.368 & -0.676 & 0.333 & 0.137 & 0.455 \\
\hline & P. semilunaris & $\mathrm{n} / \mathrm{a}$ & $\mathrm{n} / \mathrm{a}$ & & & & & & & & & & \\
\hline & N. fluviatilis & 0.850 & 1.000 & & & & & & & & & & \\
\hline & Summer & & & 0.866 & -0.082 & -0.473 & 0.058 & -0.331 & 1.205 & 0.001 & -0.721 & -1.236 & -0.179 \\
\hline & P. semilunaris & -2.007 & 1.000 & & & & & & & & & & \\
\hline \multirow{8}{*}{ Manyas } & Autumn & & & -2.221 & -0.379 & -1.433 & 6.046 & -0.527 & -0.842 & 2.609 & -3.698 & -5.768 & -4.302 \\
\hline & N. fluviatilis & $\mathrm{n} / \mathrm{a}$ & $\mathrm{n} / \mathrm{a}$ & & & & & & & & & & \\
\hline & Winter & & & -0.690 & -0.316 & -0.009 & -0.241 & 0.816 & 0.512 & -2.069 & -0.329 & 2.247 & -3.317 \\
\hline & N. fluviatilis & -3.373 & 1.000 & & & & & & & & & & \\
\hline & Spring & & & 0.256 & -0.012 & -0.227 & 0.170 & 0.020 & -0.018 & 0.111 & -0.094 & 0.175 & -0.087 \\
\hline & N. fluviatilis & -25.150 & 1.000 & & & & & & & & & & \\
\hline & Summer & & & 1.147 & -0.250 & -1.107 & -0.569 & -0.450 & 0.071 & 0.849 & -0.790 & -0.395 & 1.972 \\
\hline & N. fluviatilis & 0.720 & 1.000 & & & & & & & & & & \\
\hline \multirow{12}{*}{ Uluabat } & Autumn & & & -1.342 & 3.539 & -0.315 & -2.826 & -1.218 & -0.614 & -0.528 & 0.683 & -4.455 & -3.276 \\
\hline & P. semilunaris & 2.074 & 2.795 & & & & & & & & & & \\
\hline & N. fluviatilis & 0.716 & 1.000 & & & & & & & & & & \\
\hline & Winter & & & 5.183 & 0.987 & -4.503 & -1.204 & -2.624 & 1.342 & -0.383 & -1.069 & 2.334 & -5.338 \\
\hline & P. semilunaris & -0.886 & 1.000 & & & & & & & & & & \\
\hline & N. fluviatilis & -2.808 & 1.000 & & & & & & & & & & \\
\hline & Spring & & & 0.054 & -0.381 & -0.231 & -1.378 & -0.377 & -0.969 & -1.591 & -1.334 & 0.251 & -0.161 \\
\hline & P. semilunaris & $\mathrm{n} / \mathrm{a}$ & $\mathrm{n} / \mathrm{a}$ & & & & & & & & & & \\
\hline & N. fluviatilis & -2.047 & 1 & & & & & & & & & & \\
\hline & Summer & & & 0.381 & 0.064 & -0.017 & 0.638 & 0.125 & 0.266 & 0.933 & 1.023 & -0.861 & -1.597 \\
\hline & P. semilunaris & -2.007 & 1.000 & & & & & & & & & & \\
\hline & N. fluviatilis & -3.641 & 1.000 & & & & & & & & & & \\
\hline
\end{tabular}

et al., 2012). Other studies have suggested, however, that other populations either show no choice in substrate type (Erös et al., 2005) or for fine substrates (Gürsoy Gaygusuz et al., 2010). This difference might, however, just relate to a lack of larger material in the substrates measured in the latter study, since the streams were relatively small and had a low velocity (Gürsoy Gaygusuz et al., 2010). In invasive $P$. semilunaris lake populations in North America, the species occurs in riprap habitats (Jude and DeBoe, 1996), but not in fine substrates (Kocovsky et al., 2011). In our results, the use of stony substrates was only apparent in $P$. semilunaris in winter in Lake İznik. The only location where fine substratum was used was in Lake Sapanca, where the species was present around the mouth of the streams flowing into the lake. However, large rocks are only used when they are smaller than $40 \mathrm{~cm}$ diameter (Janáč et al., 2012) because the larger stones are associated with silt or did not provide sufficient interstitial space (Polačik et al., 2008, 2009). These results have important implications for their invasion risk management, as they suggest that habitat structure and substrate are unlikely to be limiting factors in their colonisation and establishment processes, and thus a wide range of habitats will be vulnerable to their invasion.

There is relatively less information available on the habitat use of $N$. fluviatilis. The main habitat requirement of $N$. fluviatilis has consistently been demonstrated as shorelines with sandy and gravel substrates (Čápová et al., 2008). This habitat use is thought to assist predator avoidance (Holčík et al., 2003), although it is also considered that their strong presence on sandy substrata could inhibit the expansion of their invasive range (Č́ápová et al., 2008; Piria et al., 2016). Indeed, previous data on habitat uses of $N$. fluviatilis has also demonstrated their use of sandy substrata in the shoreline (Erös et al., 2005; Adámek et al., 2007; Borcherding et al., 2013; Piria et al., 2016), which was also detected here. Direct comparison of the present results on seasonal habitat uses of $N$. fluviatilis is only possible with Erös et al. (2005), who 

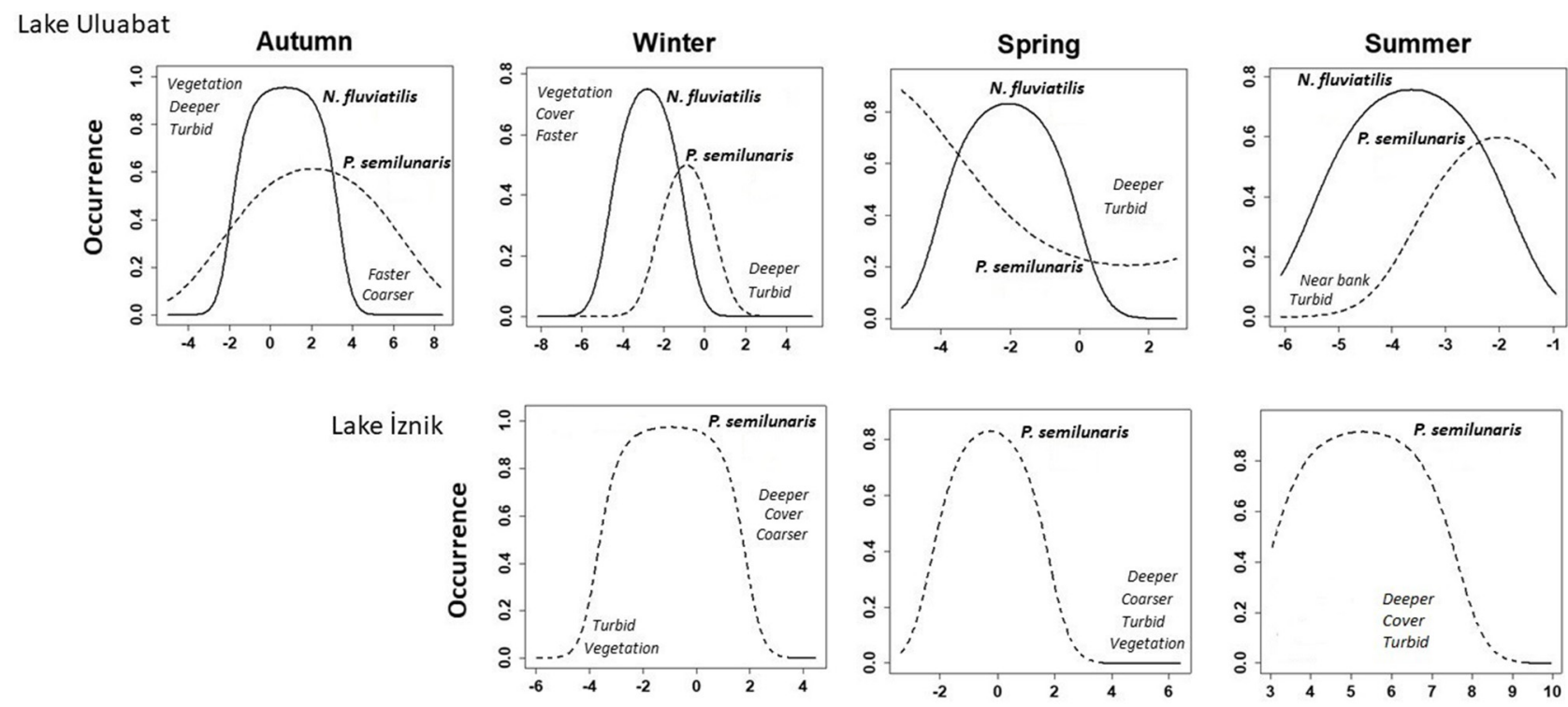

Lake Manyas
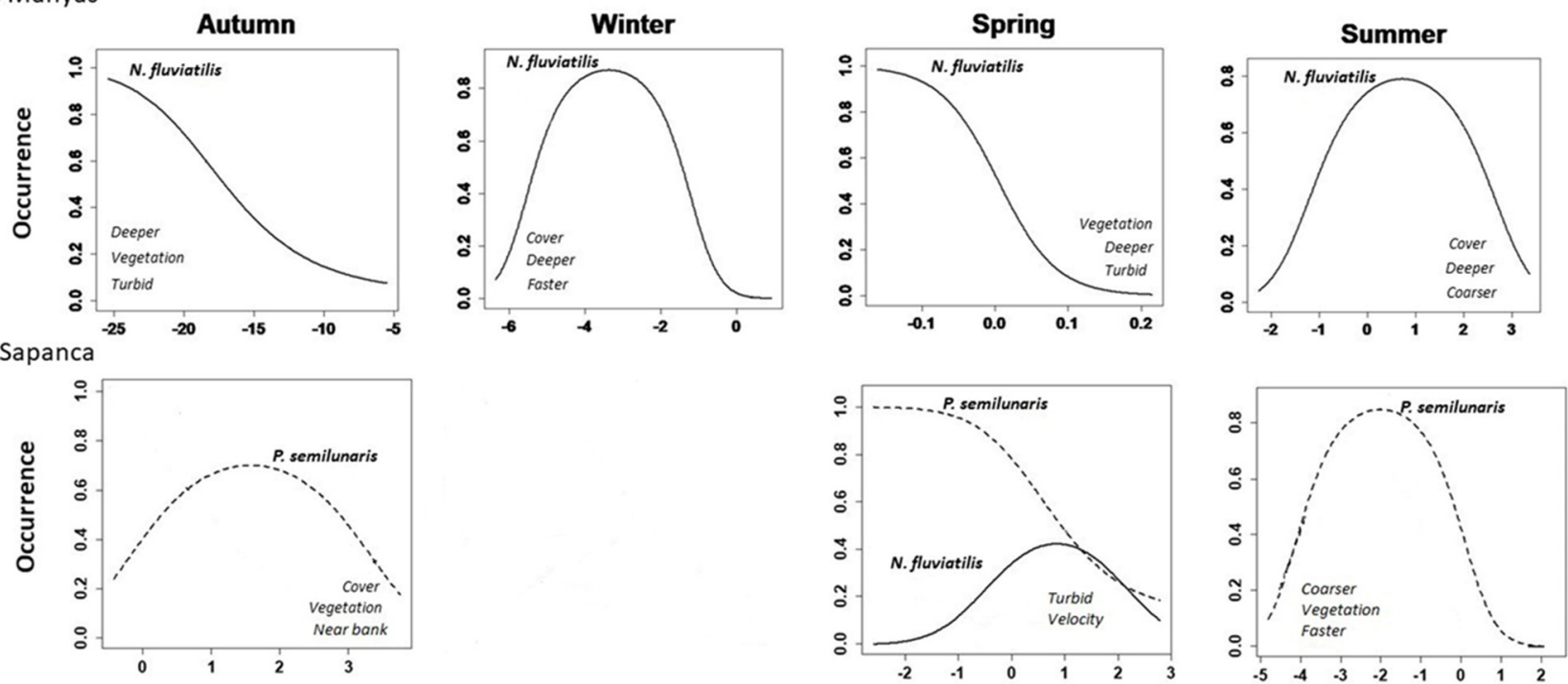

Microhabitat (Latent variables)

Fig. 2. Constrained Quadratic Ordination (CQO) plots for Western tubenose goby Proterorhinus semilunaris and monkey goby Neogobius fluviatilis sampled from four lakes in Marmara Region by season. A summary indication of the main microhabitat features is provided on the negative and positive boundaries of the microhabitat (latent) variable axis.

presented similar data from littoral zone of the Danube in Hungary. Notably, they detected seasonal differences in $N$. fluviatilis abundance in some specific habitats (e.g. Erös et al., 2005), a contrast to our results that showed minimal differences between seasons. The only consistency in our results with Erös et al. (2005) was the presence of $N$. fluviatilis in habitats away from the shore in spring. However, the spring habitats used by $N$. fluviatilis in the Danube were of high velocity and of gravel substratum with decreasing water depth (Erös et al., 2005), the opposite of our results.

Across both gobies, the four lakes and all seasons, their habitat uses were thus highly variable. This plasticity, in conjunction with other traits, including a generalist life history, plasticity in growth and capability of shifting reproductive features, is likely to confer considerable advantages in their establishment and invasion (e.g. Tarkan et al., 2018; Karakuş et al., 2018; Top et al., 2018). There was more evidence of some specialisation in the habitat uses of $N$. fluviatilis (e.g. for fine substratum), suggesting that $P$. semilunaris is more general and so more probable to successfully establish and invade new areas following introduction, despite their current spatial restriction to European water courses and North American lakes (Vanderploeg et al., 2002). Moreover, our results for P. semilunaris suggest they will be able to continue to spread in environments that provide substrata of medium sized stones with interstitial spaces and shallow waters of low velocity. Although some contrasting habitats might slow the spread of $P$. semilunaris (e.g. absence of vegetation, water with high 
velocity), the strong occurrence of $N$. fluviatilis on sandy habitats has not prevented their invasion (Copp et al., 2005; Grabowska et al., 2009; Jakovlič et al., 2015). Invasions of these gobies are thus unlikely to be inhibited by habitat availability, with their high plasticity in habitat use ensuring to be able to adapt to most new environments. These findings are important in the context of horizon scanning exercises and invasion risk assessment processes, as they now can be completed using information on the habitat uses of both fishes that show high plasticity.

Acknowledgements. This study was supported by the Scientific \& Technological Research Council of Turkey (Tübitak) (Project No: 114Y009). The authors thank Ali Özden, who facilitated the sampling in Lake Manyas.

\section{References}

Adámek Z, Andreji J, Gallardo JM. 2007. Food habitats of four bottom-dwelling gobiid species at the confluence of the Danube and Hron Rivers (South Slovakia). Int Rev Hydrobiol 92: 554-563.

Akçaalan R, Mazur-Marzec H, Zalewska A, Albay M. 2009. Phenotypic and toxicological characterization of toxic Nodularia spumigena from a freshwater lake in Turkey. Harmful Algae 8: 273-278.

Albay M, Akçaalan R. 2003. Comparative study of periphyton colonisation on common reed (Phragmites australis) and artificial substrate in a shallow lake, Manyas, Turkey. Hydrobiology 506509: 531-540.

Antsulevich A. 2007. First records of the tubenose goby Proterorhinus marmoratus (Pallas, 1814) in the Baltic Sea. Aquat Invasions 2: 468-470.

Arslan N, Aylk Ö, Sahin Y. 2010. Diversity and structure of Chrinomidae (Diptera) limnofauna of Lake Uluabat, a Ramsar site of Turkey, and their relation to environmental variables. Turkish $J$ Fish Aquat Sci 10: 315-322.

Berg LS. 1949. Freshwater Fishes of the U.S.S.R. and Adjacent Countries, Nauk SSSR, Moscow 1382 p.

Beyer K, Copp GH, Gozlan RE. 2007. Microhabitat use and interspecific associations of introduced topmouth gudgeon Pseudorasbora parva and native fishes in a small stream. $J$ Fish Biol 71: 224-238.

Britton JR, Copp GH, Brazier M, Davies GD. 2011. A modular assessment tool for managing introduced fishes according to risks of species and their populations, and impacts of management actions. Biol Invasions 13: 2847-2860.

Borcherding J, Dolina M, Heermann L, et al. 2013. Feeding and niche differentiation in three invasive gobies in the Lower Rhine, Germany. Limnologica 43: 49-58.

Copp GH. 1989. Electrofishing for fish larvae and juveniles: equipment modifications for increased efficiency with short fishes. Aquacult Fish Manag 20: 453-462.

Copp GH, Bianco PG, Bogutskaya N, et al. 2005. To be, or not to be, a non-native freshwater fish? J Appl Ichthyol 21: 242-262.

Copp GH, Vilizzi L, Mumford J, Fenwick GV, Godard MJ, Gozlan RE. 2009. Calibration of FISK, an invasiveness screening tool for nonnative freshwater fishes. Risk Anal 29: 457-467.

Copp GH, Russell IC, Peeler EJ, et al. 2016. European Non-native Species in Aquaculture Risk Analysis Scheme - a summary of assessment protocols and decision support tools for use of alien species in aquaculture. Fish Manag Ecol 23: 1-1.
Č́ápová M, Zlatnická I, Kováč V, Katina S. 2008. Ontogenetic variability in the external morphology of monkey goby, Neogobius fluviatilis (Pallas, 1814) and its relevance to invasion potential. Hydrobiologia 607: 17-26.

Çınar Ş, Küçükkara R, Balık İ, et al. 2013. Uluabat (Apolyont) Gölü'ndeki balık faunasının tespiti, tür kompozisyonu ve ticari avcılığının türlere göre dağılımı. J Fish Sci 7: 309-316.

Davidson AM, Jennions M, Nicotra AB. 2011. Do invasive species show higher phenotypic plasticity than native species and, if so, is it adaptive? A meta-analysis. Ecol Lett 14: 419-431.

Dillon A, Stepien CA. 2001. Genetic and Biogeographic Relationships of the Invasive Round (Neogobius melanostomus) and Tubenose (Proterorhinus marmoratus) Gobies in the Great Lakes Versus Eurasian Populations. J Great Lakes Res 27: 267-280.

Erös T, Sevcik A, Toth B. 2005. Abundance and night-time habitat use patterns of Ponto-Caspian gobiid species (Pisces, Gobiidae) in the litoral zone of the river Danube, Hungary. J Appl Ichthyol 21: 350 357.

Geldiay R, Balık S. 2009. The Freshwater Fishes of Turkey. Ege Üniversitesi Fen Fakültesi Kitaplar Serisi, İzmir, Turkey, 519 p.

Gozlan RE, Britton JR, Cowx IG, Copp GH. 2010. Current knowledge on non-native freshwater fish introductions. $J$ Fish Biol 76: 751-786.

Grabowska J, Pietraszewski D, Ondračková M. 2008. Tubenose goby Proterorhinus marmoratus (Pallas, 1814) has joined three other Ponto-Caspian gobies in the Vistula River (Poland). Aquat Invasions 3: 261-265.

Grabowska J, Grabowski M, Kostecka A. 2009. Diet and feeding habits of monkey goby (Neogobius fluviatilis) in a newly invaded area. Biol Invasions 11: 2161-2170.

Gürsoy Gaygusuz Ç, Tarkan AS, Gaygusuz Ö. 2010. Diel changes in feeding activity, microhabitat preferences and abundance of two freshwater fish species in small temperate streams. Ekoloji (Turkey) 19: 15-24.

Holčík J, Stránai I, Andreji J. 2003. The further advance of Neogobius fluviatilis (Pallas, 1814) (Pisces, Gobiidae) upstream of the Danube. Biología (Bratislava) 58: 967-973.

Jakovlič I, Piria M, Šprem N, Tomljanovič T, Matulič D, Treer T. 2015. Distribution, abundance and condition of invasive PontoCaspian gobies Ponticola kessleri (Günther, 1861), Neogobius fluviatilis (Pallas, 1814), and Neogobius melanostomus (Pallas, 1814) in the Sava River basin, Croatia. J Appl Ichthyol 31: 888-894.

Janáč M, Valová Z, Jurajda P. 2012. Range expansion and habitat preferences of nonnative $0+$ tubenose goby (Proterorhinus semilunaris) in two lowland rivers in the Danube basin. Fund Appl Limnol 181: 73-85.

Jude DJ, Reider RH, Smith GR. 1992. Establishment of Gobiidae in the Great Lakes basin. Can J Fish Aquat Sci 49: 416-421.

Jude DJ, DeBoe SF. 1996. Possible impact of gobies and other introduced species on habitat restoration efforts. Can J Fish Aquat Sci 53: 136-141.

Karakuş U, Top N, Tepeköy EG, Britton JR, Tarkan AS. 2018. Life history characteristics of the potentially invasive Ponto-Caspian goby Neogobius fluviatilis in natural lakes from its native range (Black Sea region of Turkey). Mar Freshw Res 69: 1544-1556.

Kocovsky PM, Tallman JA, Jude DJ, Murphy DM, Brown JE, Stepien CA. 2011. Expansion of tubenose gobies Proterorhinus semilunaris into western Lake Erie and potential effects on native species. Biol Invasions 13: 2775-2784.

Konečná M, Jurajda P. 2012. Population structure, condition, and reproduction characteristics of native monkey goby, Neogobius fluviatilis (Actinopterygii: Perciformes Gobiidae), in the Bulgarian Danube. Acta Ichthyol Piscat 42: 321-327. 
Kornis MS, Vander Zanden MJ. 2010. Forecasting the distribution of the invasive round goby (Neogobius melanostomus) in Wisconsin tributaries to Lake Michigan. Can J Fish Aquat Sci 67: $553-562$.

Kornis MS, Mercado-Silva N, Vander Zanden MJ. 2012. Twenty years of invasion: a review of round goby Neogobius melanostomus biology, spread and ecological implications. J Fish Biol 80: $235-285$.

Lockwood JL, Hoopes MF, Marchetti MP. 2007. Invasion ecology. London: Blackwell, 444 p.

Lusk S, Halačka K. 1995. The first finding of the tubenose goby, Proterorhinus marmoratus in the Czech Republic. Folia Zool 44: 90-92.

Magnin G, Yarar M. 1997. Important Bird Nesting Sites of Turkey. Society for Protection of Nature-DHKD, İstanbul, $313 \mathrm{p}$.

Naseka AM. 2005. New data on the historical and expanded range of Proterorhinus marmoratus (Pallas, 1814) (Teleostei: Gobiidae) in eastern Europe. J Appl Ichthyol 21: 300-305.

Nelva A, Persat H, Chessel D. 1979. Une nouvelle méthode d'étude des peuplements ichtyologiques dans les grands cours d'aeu par échantillonnage ponctuel d'abodance. C R Acad Sci III Paris [in French] 289: 1295-1298.

Numann W. 1958. Research on limnological and fishery sciences in various lakes of Anatolia and a special study on common carp living in these lakes. Monography from İstanbul University Science Faculty Hydrobiology Research Institute No: 7, İstanbul [in Turkish], $114 \mathrm{p}$.

Özuluğ M, Altun Ö, Meriç N. 2005. On the fish fauna of Lake İznik (Turkey). Turk J Zool 29: 371-375.

Pagnucco KS, Maynard GA, Fera SA, Yan ND, Nalepa TF, Ricciardi A. 2015. The future of species invasions in the Great Lakes-St Lawrence River basin. J Great Lakes Res 41: 96-107.

Piria M, Jakšić G, Jakovlić I, Treer T. 2016. Dietary habits of invasive Ponto-Caspian gobies in the Croatian part of the Danube River basin and their potential impact on benthic fish communities. $\mathrm{Sci}$ Total Environ 540: 386-395.

Polačik M, Janáč M, Trichkova T, Vasillev M, Keckeis H, Jurajda P. 2008. The distribution and abundance of the Neogobius fishes in their native range (Bulgaria) with notes on the non-native range in the Danube River. Arch Hydrobiol Suppl 166, Large Rivers 18: 193-208.

Polačik M, Janáč M, Jurajda P, Adámek Z, Ondračková M, Trichkova T, Vassilev M. 2009. Invasive gobies in the Danube: invasion success facilitated by availability and selection of superior food resources. Ecol Freshwat Fish 18: 640-649.

R Development Core Team. 2015. R: A Language and Environment for Statistical Computing. Vienna: R Foundation for Statistical Computing.

Rizevsky V, Pluta M, Leschenko A, Ermolaeva I. 2007. First record of the invasive Ponto-Caspian tubenose goby Proterorhinus marmor- atus (Pallas, 1814) from the River Pripyat, Belarus. Aquat Invasions 2: 275-277.

Roche KF, Janáč M, Jurajda P. 2013. A review of Gobiid expansion along the Danube-Rhine corridor geopolitical change as a driver for invasion. Knowl Manag Aquat Ecosyst 411: 01.

Roy HE, Peyton J, Aldridge DC, et al. 2014. Horizon scanning for invasive alien species with the potential to threaten biodiversity in Great Britain. Global Change Biol 20: 3859-3871.

Seebens H, Blackburn TM, Dyer EE, et al. 2017. No saturation in the accumulation of alien species worldwide. Nat Commun 8: 14435.

Sindilariu PD, Freyhof J, Wolter C. 2006. Habitat use of juvenile fish in the lower Danube and the Danube Delta: implications for ecotone connectivity. Hydrobiol 571: 51-61.

Svetovidov AN. 1964. Fishes of the Black sea. Nauka, Moscow, $550 \mathrm{p}$.

Tarkan AS, Karakuş U, Tepeköy EG, et al. 2018. Trophic interactions of two Ponto-Caspian gobies in the Turkish part of their native range. Turk J Fish Aquat Sci 18: 1279-1286.

Top N, Tarkan AS, Vilizzi L, Karakuş U. 2016. Microhabitat interactions of non-native pumpkinseed Lepomis gibbosus in a Mediterranean-type stream suggest no evidence for impact on endemic fishes. Knowl Manag Aquatic Ecosyst 417: 36.

Top N, Karakuş U, Tepeköy EG, Britton JR, Tarkan AS. 2018. Plasticity in life history traits of the native Proterorhinus semilunaris suggests high adaptive capacity in its invasive range. Knowl Manag Aquat Ecocsyst 419: 48.

Van Kessel N, Dorenbosch M, De Boer MRM, Leuveng RSEW, Van Der Velde G. 2011. Competition for shelter between four invasive gobiids and two native benthic fish species. Curr Zool 57: 844-851.

Vanderploeg HA, Nalepa TF, Jude DJ, et al. 2002. Dispersal and emerging ecological impacts of Ponto-Caspian species in the Laurentian Great Lakes. Can J Fish Aquat Sci 59: 1209-1228.

Všetičková L, Janáč M, Vašek M, Roche K, Jurajda P. 2014. Nonnative western tubenose gobies Proterorhinus semilunaris show distinct site, sex and age-related differences in diet. Knowl Manag Aquat Ecosyst 414: 10.

Vilizzi L, Stakènas S, Copp GH. 2012. Use of constrained additive and quadratic ordination in fish habitat studies: an application to introduced pumpkinseed (Lepomis gibbosus) and native Brown trout (Salmo trutta) in an English stream. Fund Appl Limnol 180: 69-75.

Wiesner C. 2005. New records of non-indigenous gobies (Neogobius spp.) in the Austrian Danube. J Appl Ichthyol 21: 324-327.

Yee TW. 2004. A new technique for maximum-likelihood canonical Gaussian ordination. Ecol Monogr 74: 685-701.

Yee TW. 2006. VGAM Family Functions for Reduced-Rank Regression and Constrained Ordination. Beta version 0.6-5. http://www.stat.auckland.ac.nz/ yee/VGAM/doc/rrvglm.pdf.

Cite this article as: Top N, Karakus U, Tepeköy EG, Britton JR, Tarkan AS. 2019. Plasticity in habitat use of two native Ponto-Caspian gobies, Proterorhinus semilunaris and Neogobius fluviatilis: implications for invasive populations. Knowl. Manag. Aquat. Ecosyst., $420,40$. 